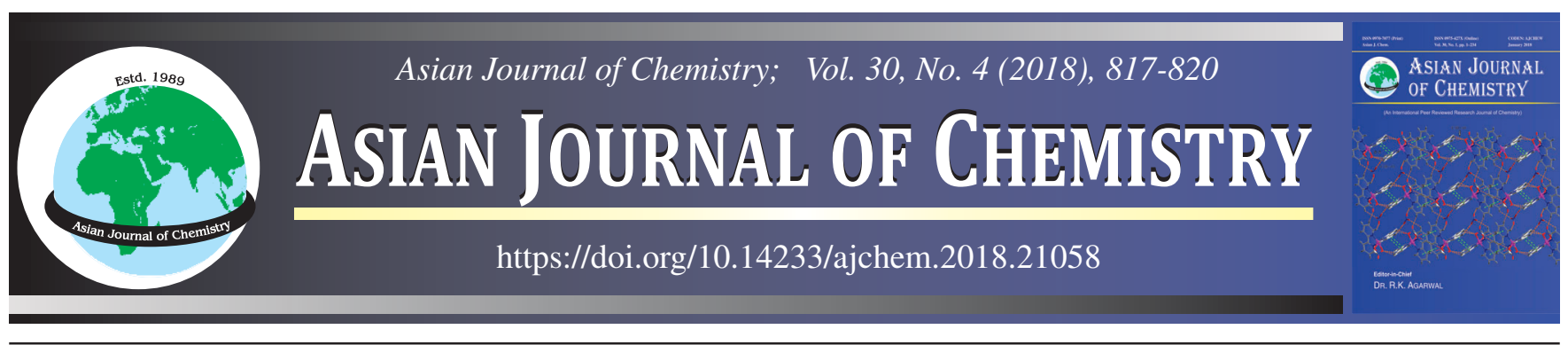

\title{
Ultrasonication Assisted Development of New Greener Method for Extraction of Cypermethrin and Transfluthrin from Various Samples: A Forensic Approach
}

\author{
P.N. PathaK ${ }^{1}$, S.G. PANDE ${ }^{1}$, A.A. SukhadeVe ${ }^{1}$, A.A. $\mathrm{SAHU}^{2}$ and D.S. Bhagat ${ }^{1, *}$
}

${ }^{1}$ Department of Forensic Chemistry and Toxicology, Government Institute of Forensic Science, Aurangabad-431 004, India

${ }^{2}$ Department of Forensic Science, Government Institute of Forensic Science, Aurangabad-431 004, India

*Corresponding author: Tel/Fax: +91 240 2400219; E-mail: dsbhagat999@gmail.com

Received: 22 September 2017;

Accepted: 11 January 2018;

Published online: 28 February 2018;

AJC-18792

In present work, we developed an extraction method of two pyrethroids viz., cypermethrin and transfluthrin from soil, cloth pieces and household insecticides by using ultrasonicator. Extractions were done in xylene and ethanol solvents. Confirmation of pyrethroids was performed using thin layer chromatography (TLC), UV-visible, FT-IR spectroscopy and LC-MS.

Keywords: Pyrethroids, Cypermethrin, Transfluthrin, Ultrasonication, Household insecticide, Agriculture insecticide.

\section{INTRODUCTION}

Pyrethrum is a naturally occurring chemical, which is found in certain chrysanthemum flowers (Chrysanthemum cinerarifolium). Pyrethrum extract contains chemicals that have insecticidal properties called as 'pyrethrins'. Pyrethrins are mostly used in household insecticides to control insects on pets or livestock. Pyrethrins break down quickly, when they are exposed to sunlight [1]. Pyrethroids are synthetic chemicals that are similar in structure to the pyrethrins and more toxic to insects and mammals. Also they last longer in the environment than pyrethrins. Pyrethrins and pyrethroids are mostly used with other chemicals called synergists to enhance the insecticidal activity [2]. Pyrethroids are of two types, type I and type II. Type I pyrethroids are with the basic cyclopropane carboxylic ester structure and insecticidal activity of synthetic pyrethroids was enhanced by addition of a cyano group at the benzyl carbon atom to give $\alpha$-cyano pyrethroids such as cypermethrin which is type II. Type I compounds are generally found to produce the $\mathrm{T}$ (tremor) syndrome and Type II compounds CS (choreoathetosis with salivation) syndrome [3].

Pyrethroid enters into human body through inhalation, dermal exposure, eating contaminated food or drinking contaminated water. Pyrethroid insecticides act on the nerves system by inducing a transient increase in sodium permeability of the nerve membrane during excitation, of both insects and higher animals. Pyrethroids impair ion transport through the membrane of nerve axons, which causes muscular paralysis in the insect and death follows a nervous system impairment that occurs a few minutes after pesticide absorption $[4,5]$. Pyrethroids keep the sodium channel open for long time which causes a prolonged flow of sodium current [6]. The interaction between the pyrethroids and macromolecular components of the sodium channel is reversible. Removal of pyrethroids from the nervous system is rapid that is a $50 \%$ recovery of effects is possible to occur [7]. Pyrethroids penetrate slowly through skin and may cause typical local paraesthesia [8]. Pyrethroids are distributed to all tissues and are concentrated in tissues with high lipid contents [9]. Pyrethroids are rapidly distributed into the body and metabolized in liver by hydrolases and cytochrome P-450 dependent monooxygenases, with breakdown of the molecule at oxygen bridge to form acids and alcohols which has lower toxicity than the parent compounds $[10,11]$. Pyrethroids do not accumulate in the body due to rapid excretion through urine and faeces. The main metabolites found in urine for many pyrethroids are 3-phenoxybenzoic acid (3-PBA) and the 3-(4'-hydroxyphenoxy)benzoic acid (4HPBA) [12]. Skin exposure causes local skin irritation [13], burning and blisters and mild eye irritation may occur due to ocular exposure. Pyrethroids inhalation may cause nasal and respiratory irritation. Occupational exposure may produce symptoms and signs of pulmonary tract irritation and systemic effects [14]. Pyrethroid ingestion causes a sore throat, nausea, vomiting, abdominal pain and mouth ulceration or dysphagia [15]. Poor handling of concentrated solutions or prolong exposure of pyrethroids can cause systemic effect. In T (tremor) syndrome, the poisoning begins with aggressiveness, increased sensitivity for external stimuli followed by fine tremors which 
becomes more severe and increase body temperature. CS syndrome shows abnormal behaviour, tremors in whole body, salivation, bradycardia and choreoathetosis. Sometimes it also effect on antagonism of GABA receptors [16].

Cypermethrin (Fig. 1) is a synthetic pyrethroid. It is active against a large number of insects such as hemipetera and coleoptera which are found on cotton, fruit, vegetables and other crops. Cypermethrin is obtained by converting methyl (1RS)cis, trans-3-(2,2-dichlorovinyl)-2,2-dimethylcyclopropanecarboxylate to the corresponding acid chloride and then reacting this intermediate with 3-phenoxybenzaldehyde in the presence of sodium cyanide [17].<smiles>CC1(C)C(C=C(Cl)Cl)C1C(=O)OC(C#N)c1cccc(Oc2ccccc2)c1</smiles>

Fig. 1. Structure of cypermethrin

The symptoms of cypermethrin poisoning include dizziness, nausea, headaches, burning skin, fatigue, muscle twitching, coma and death may occur due to cypermethrin contaminated food [18]. In some cases cypermethrin causes delayed in mental development $[19,20]$. The effect of cypermethrin on dopamine activity in brain was observed in the studies on mice [21]. Cypermethrin can cause cancer and tumor [22]. It also affects reproductive system by reducing sperm production and motility in male rodent $[23,24]$.

Transfluthrin (Fig. 2) is a fast acting insecticide, which is mostly used in household insecticide against flying insects such as mosquitoes and flies. It also acts against material pests, such as moths. Transfluthrin is synthesized by using tetrafluorobenzyl alcohol and trans-2,2-dimethyl-3-(2,2-dichlorovinyl)cyclopropanecarboxylate. It can be synthesized from reactions of optically active 1R-trans-permethric acid chloride or derivatives with the tetrafluorobenzyl alcohol [25].

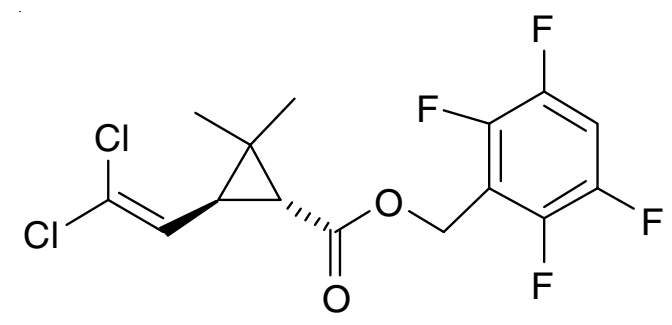

Fig. 2. Structure of transfluthrin

From the literature review it was found that extraction of pyrethroid or pesticides from soil was performed using ultrasonication and Soxhlet method [26], from wool by using supercritical fluid extraction [27], from mosquito repellent [28,29], milk [30], honey [31], fruits and vegetables [32] and from water using ultrasound-assisted emulsification-extraction (UAEE) [33]. The matrix solid-phase dispersion (MSPD) method was developed for the determination of 13 pyrethroid insecticide residues in goat tissues (liver, kidney, muscle and heart) and milk using gas chromatography electron ionization mass spectrometry [34].
EXPERIMENTAL

Chemicals were purchased from Sigma Aldrich chemical and Thermofisher Scientific Company. Cymbush (Cypermethrin $25 \%$ EC insecticide), Hit spray, Cockroach and ant killer chalk (Zee), were used as source of cypermethrin. Good Knight fast guard for Transfluthrin was purchased from commercial supplier. The analysis of sample was carried out using UV-VIS Perkin Elmer, lambda 35 systems equipped with a double beam deuterium lamp having wavelength range from 200-700 nm. FT-IR [Make: Bruker, Model: ALPHA] analysis were carried out in wavelength range from $4000-400 \mathrm{~cm}^{-1}$. The process of extraction was carried out by using ultrasonicator. To obtain pure sample preparative TLC (thin layer chromatography) was performed.

Sample preparation: The soil sample was collected from campus of Government Institute of Forensic Science, Aurangabad and then it was kept in hot air oven for $30 \mathrm{~min}$ at $110{ }^{\circ} \mathrm{C}$ for drying. $5 \mathrm{~g}$ of soil was taken in 3 crucibles and spiked with 10 , 7 and $5 \%$ cypermethrin solution, respectively. Similarly clean cloth pieces were spiked with 10,7 and $5 \%$ cypermethrin solution, respectively. The samples were kept for $24 \mathrm{~h}$. Hit insecticide spray was spread on cloth piece for $5 \mathrm{~s}$ and kept for $24 \mathrm{~h}$. Cockroach and ant killer chalk was analyzed by weighing $2 \mathrm{~g}$ of chalk and extracting by ultrasonication.

Extraction by ultrasonicator: The spiked soil samples were extracted in $10 \mathrm{~mL}$ xylene by keeping it in ultrasonication for $30 \mathrm{~min}$. The spiked cloth piece with 10, 7 and $5 \%$ cypermethrin solution and hit insecticide spray, were extracted in $5 \mathrm{~mL}$ ethanol by keeping it in ultrasonication for $30 \mathrm{~min} .2 \mathrm{~g}$ of cockroach and ant killer chalk was extracted in $5 \mathrm{~mL}$ ethanol by ultrasonication for $30 \mathrm{~min}$ at room temperature. All the extracts were filtered through Whatman filter paper- 41 and analyzed by TLC, UV-visible spectrophotometer and FTIR. $1 \mathrm{~mL}$ of extracted samples were separated by performing preparative TLC in hexane:acetone (8:2) as solvent system. Separated samples were scrapped out and dissolved in $5 \mathrm{~mL}$ ethanol.

Analysis by TLC: Thin layer of silica gel-G was prepared on TLC plate and kept in hot air oven for $30 \mathrm{~min}$ at $110^{\circ} \mathrm{C}$ for activation. These plates were used for analysis. UV cabinet and iodine fumes were used as visualizing agents.

Analysis by UV-visible spectrophotometer: In UV-visible spectrophotometer analysis, firstly preparative TLC was performed using pure cypermethrin (25\%) and 10, 7 and $5 \%$ cypermethrin extract in xylene. Solvent system was hexane: acetone (8:2). After running the TLC, separated samples were scrapped and dissolved in $5 \mathrm{~mL}$ ethanol. Then filtered and transferred to vials, whose empty weights were already taken. The extracts were evaporated in vials and again weight of vials with residues were taken (Table-1). From the obtained residues of pure sample, 50, 100, 150, 200, 250, 300 ppm dilutions

\begin{tabular}{lccc}
\multicolumn{4}{c}{ TABLE-1 } \\
WEIGHT OF RESIDUES \\
\hline \multicolumn{1}{c}{ Sample } & $\begin{array}{c}\text { Wt. of empty } \\
\text { vial }(\mathrm{g})\end{array}$ & $\begin{array}{c}\text { Wt. of vial + } \\
\text { residue }(\mathrm{g})\end{array}$ & $\begin{array}{c}\text { Wt. of } \\
\text { residue }(\mathrm{g})\end{array}$ \\
\hline Pure sample & 0.74 & 0.76 & 0.02 \\
10 \% extract in xylene & 0.74 & 0.75 & 0.01 \\
$7 \%$ extract in xylene & 0.74 & 0.75 & 0.01 \\
$5 \%$ extract in xylene & 0.74 & 0.75 & 0.01 \\
\hline
\end{tabular}




\begin{tabular}{lcccc|ccc}
\hline & \multicolumn{4}{c}{ TABLE-2 } \\
& \multicolumn{4}{c}{ RESULTS OF THIN LAYER CHROMATOGRAPHY } \\
\hline \multirow{2}{*}{ Solvent system } & \multirow{2}{*}{ Ratio } & \multicolumn{2}{c}{$\mathrm{R}_{\mathrm{f}}$ value of soil extract of cypermethrin } & \multicolumn{2}{c}{$\mathrm{R}_{\mathrm{f}}$ value of cloth extract of cypermethrin } \\
\cline { 3 - 8 } & & $10 \%$ & $7 \%$ & $5 \%$ & $10 \%$ & $7 \%$ & $5 \%$ \\
\hline Hexane:acetone & $8: 2$ & 0.32 & 0.34 & 0.35 & 0.30 & 0.39 & 0.40 \\
Toluene:ethyl acetate & $8: 2$ & 0.67 & 0.64 & 0.61 & 0.90 & 0.90 \\
\hline
\end{tabular}

TABLE-3

THIN LAYER CHROMATOGRAPHY OF CYPERMETHRIN AND TRANSFLUTHRIN

\begin{tabular}{lcccc}
\hline \multicolumn{1}{c}{ Solvent system } & Ratio & $\begin{array}{c}\mathrm{R}_{\mathrm{f}} \text { value of cypermethrin } \\
\text { extract from hit spray }\end{array}$ & $\begin{array}{c}\mathrm{R}_{\mathrm{f}} \text { value of cypermethrin extract from } \\
\text { cockroach and ant killer chalk }\end{array}$ & $\begin{array}{c}\mathrm{R}_{\mathrm{f}} \text { value of transfluthrin extract } \\
\text { from good knight fast guard }\end{array}$ \\
\hline Hexane:acetone & $8: 2$ & 0.54 & 0.62 & 0.87 \\
Toluene:ethyl acetate & $8: 2$ & 0.62 & 0.94 & 0.59 \\
\hline
\end{tabular}

were made and calibration curve was plotted. Similarly dilutions of 10,7 and $5 \%$ cypermethrin extract from soil, cloth piece, chalk sample and hit spry sample were made and UV analysis was done.

\section{RESULTS AND DISCUSSION}

In TLC analysis, the $R_{f}$ value of pure cypermethrin was found to be 0.31 in solvent system hexane:acetone [8:2]. The $\mathrm{R}_{\mathrm{f}}$ values of extracted samples were compared with pure cypermethrin (Tables 2 and 3). Iodine fuming and UV light (short) were found convenient as visualizing agent. In UV analysis the calibration curve of concentration of cypermethrin in ppm vs. absorption was plotted (figure not shown) and the quantitative analysis of all cypermethrin extract was performed. With the help of calibration curve, the concentration of cypermethrin, in $1 \mathrm{~mL}$ of extract was found to be $225,50,100 \mathrm{ppm}$ for 10, 7 and $5 \%$ soil extract, respectively. For cloth extract it is $180,130,150 \mathrm{ppm}$ in $10,7,5 \%$ extract, respectively. For cockroach and ant killer chalk it is $560 \mathrm{ppm}$ and for hit spray $230 \mathrm{ppm}$ in $1 \mathrm{~mL}$ extract. Ethanol was found to be suitable for UV-visible spectroscopic analysis of cypermethrin. Peaks of cypermethrin were found in the range 266-276 nm of UV range (Table-4). Functional groups $\mathrm{C}-\mathrm{Cl}, \mathrm{C}-\mathrm{O}-\mathrm{C}, \mathrm{C}=\mathrm{O}, \mathrm{CN}$ were identified using FTIR (Table-5). In LC-MS analysis prominent peaks observed at $m / z=450,433,415,326,270$. The spot tests of Dragendorff's Reagent, Van Urk's Reagent, $1 \%$ aq. potassium ferricyanide were carried out on thin layer of silica gel ' $G$ ' coated on glass slide and positive results for presence of cypermethrin were obtained (Table-6).

\section{Conclusion}

From the obtained result, it is concluded that ultrasonication is the rapid, easy and greener method for extraction which

\begin{tabular}{clcc}
\multicolumn{5}{c}{ TABLE-4 } \\
\multicolumn{5}{c}{ UV-VISIBLE SPECTROSCOPY ANALYSIS } \\
\hline S. & \multicolumn{1}{c}{ Sample } & $\begin{array}{c}\lambda_{\max } \\
(\mathrm{nm})\end{array}$ & $\begin{array}{c}\text { Abs. } \\
(\mathrm{A})\end{array}$ \\
No. & & 266 & 2.89 \\
\hline 1 & Pure cypermethrin (standard) & 269 & 0.52 \\
2 & $10 \%$ extract of cypermethrin from soil & 277 & 0.08 \\
3 & $7 \%$ extract of cypermethrin from soil & 277 & 0.11 \\
4 & $15 \%$ extract of cypermethrin from soil & 273 & 1.12 \\
5 & $10 \%$ extract of cypermethrin from cloth & 273 & 0.78 \\
6 & $7 \%$ extract of cypermethrin from cloth & 273 & 1.07 \\
7 & $5 \%$ extract of cypermethrin from cloth & 267 & 3.43 \\
8 & Cypermethrin from cockroach \& ant killer chalk & 276 & 1.30 \\
9 & Cypermethrin from hit spray & & \\
\hline
\end{tabular}

\begin{tabular}{|c|c|c|}
\hline \multicolumn{3}{|c|}{$\begin{array}{c}\text { TABLE-5 } \\
\text { KEY FTIR BANDS }\left(\mathrm{cm}^{-1}\right) \text { OF } \\
\text { CYPERMETHRIN AND TRANSFLUTHRIN }\end{array}$} \\
\hline Sample & Frequency $\left(\mathrm{cm}^{-1}\right)$ & Functional group \\
\hline Pure cypermethrin & $\begin{array}{c}740.65 \\
2357.90 \\
1039.20 \\
1662.83 \\
1594.84 \\
2980.63 \\
\end{array}$ & $\begin{array}{l}\mathrm{C}-\mathrm{Cl} \text { stretch } \\
\mathrm{C} \equiv \mathrm{N} \text { stretch } \\
\mathrm{C}-\mathrm{O}-\mathrm{C} \text { stretch } \\
\mathrm{C}=\mathrm{O} \text { stretch } \\
\mathrm{C}=\mathrm{C} \text { stretch } \\
\mathrm{C}-\mathrm{H} \text { stretch }\end{array}$ \\
\hline $\begin{array}{l}10 \% \text { extract of } \\
\text { cypermethrin from } \\
\text { soil }\end{array}$ & $\begin{array}{c}679.74 \\
2280.95 \\
1047.02 \\
1886.56 \\
1591.02 \\
\end{array}$ & $\begin{array}{l}\mathrm{C}-\mathrm{Cl} \text { stretch } \\
\mathrm{C} \equiv \mathrm{N} \text { stretch } \\
\mathrm{C}-\mathrm{O}-\mathrm{C} \text { stretch } \\
\mathrm{C}=\mathrm{O} \text { stretch } \\
\mathrm{C}=\mathrm{C} \text { stretch }\end{array}$ \\
\hline $\begin{array}{l}7 \% \text { extract of } \\
\text { cypermethrin from } \\
\text { soil }\end{array}$ & $\begin{array}{c}635.61 \\
2281.24 \\
1028.31 \\
1884.07 \\
1594.69 \\
\end{array}$ & $\begin{array}{l}\mathrm{C}-\mathrm{Cl} \text { stretch } \\
\mathrm{C} \equiv \mathrm{N} \text { stretch } \\
\mathrm{C}-\mathrm{O}-\mathrm{C} \text { stretch } \\
\mathrm{C}=\mathrm{O} \text { stretch } \\
\mathrm{C}=\mathrm{C} \text { stretch }\end{array}$ \\
\hline $\begin{array}{l}5 \% \text { extract of } \\
\text { cypermethrin from } \\
\text { soil }\end{array}$ & $\begin{array}{c}689.80 \\
2217 \\
1048 \\
1641.34 \\
2975 \\
\end{array}$ & $\begin{array}{l}\mathrm{C}-\mathrm{Cl} \text { stretch } \\
\mathrm{C} \equiv \mathrm{N} \text { stretch } \\
\mathrm{C}-\mathrm{O}-\mathrm{C} \text { stretch } \\
\mathrm{C}=\mathrm{O} \text { stretch } \\
\mathrm{C}-\mathrm{H} \text { stretch }\end{array}$ \\
\hline $\begin{array}{l}10 \% \text { extract of } \\
\text { cypermethrin from } \\
\text { cloth piece }\end{array}$ & $\begin{array}{c}687.82 \\
2364.16 \\
1070.43 \\
1658.32 \\
\end{array}$ & $\begin{array}{l}\mathrm{C}-\mathrm{Cl} \text { stretch } \\
\mathrm{C} \equiv \mathrm{N} \text { stretch } \\
\mathrm{C}-\mathrm{O}-\mathrm{C} \text { stretch } \\
\mathrm{C}=\mathrm{O} \text { stretch }\end{array}$ \\
\hline $\begin{array}{l}7 \% \text { extract of } \\
\text { cypermethrin from } \\
\text { cloth piece }\end{array}$ & $\begin{array}{c}686.38 \\
2364.35 \\
1047.06 \\
1748.81 \\
\end{array}$ & $\begin{array}{l}\mathrm{C}-\mathrm{Cl} \text { stretch } \\
\mathrm{C} \equiv \mathrm{N} \text { stretch } \\
\mathrm{C}-\mathrm{O}-\mathrm{C} \text { stretch } \\
\mathrm{C}=\mathrm{O} \text { stretch } \\
\end{array}$ \\
\hline $\begin{array}{l}5 \% \text { extract of } \\
\text { cypermethrin from } \\
\text { cloth piece }\end{array}$ & $\begin{array}{c}669 \\
2208.65 \\
1019.96 \\
1744.64 \\
\end{array}$ & $\begin{array}{l}\mathrm{C}-\mathrm{Cl} \text { stretch } \\
\mathrm{C} \equiv \mathrm{N} \text { stretch } \\
\mathrm{C}-\mathrm{O}-\mathrm{C} \text { stretch } \\
\mathrm{C}=\mathrm{O} \text { stretch }\end{array}$ \\
\hline Extract of hit sample & $\begin{array}{c}838.20 \\
1064 \\
1464.09 \\
2922\end{array}$ & $\begin{array}{l}\mathrm{C}-\mathrm{Cl} \text { stretch } \\
\mathrm{C}-\mathrm{O}-\mathrm{C} \text { stretch } \\
\mathrm{C}=\mathrm{C} \text { stretch } \\
\mathrm{C}-\mathrm{H} \text { stretch }\end{array}$ \\
\hline $\begin{array}{l}\text { Extract from ant } \\
\text { killer chalk }\end{array}$ & $\begin{array}{c}879.56 \\
2359.33 \\
1044.73 \\
1635 \\
\end{array}$ & $\begin{array}{l}\mathrm{C}-\mathrm{Cl} \text { stretch } \\
\mathrm{C} \equiv \mathrm{N} \text { stretch } \\
\mathrm{C}-\mathrm{O}-\mathrm{C} \text { stretch } \\
\mathrm{C}=\mathrm{O} \text { stretch }\end{array}$ \\
\hline $\begin{array}{l}\text { Extract of } \\
\text { transfluthrin from } \\
\text { fast guard }\end{array}$ & $\begin{array}{c}1400 \\
1069 \\
706 \\
1655 \\
1508\end{array}$ & $\begin{array}{l}\text { C-F stretch } \\
\text { C-O-C stretch } \\
\text { C-Cl stretch } \\
\mathrm{C}=\mathrm{O} \text { stretch } \\
\mathrm{C}=\mathrm{C} \text { stretch }\end{array}$ \\
\hline
\end{tabular}




\begin{tabular}{|c|c|c|c|c|}
\hline \multicolumn{5}{|c|}{$\begin{array}{c}\text { TABLE-6 } \\
\text { RESULTS OF SPOT TESTS }\end{array}$} \\
\hline S. No. & Reagent & Preparation of reagent & Colour & Ref. \\
\hline 1 & $\begin{array}{l}\text { Dragendorff's reagent }+2 \text { Drops of } \\
\text { sample extract (heat for } 5 \text { min at } 75^{\circ} \mathrm{C} \text { ) }\end{array}$ & $\begin{array}{l}\text { (a) } 2 \mathrm{~g} \text { of bismuth subnitrate }+25 \mathrm{~mL} \text { of glacial acetic acid }+100 \mathrm{~mL} \\
\text { water; (b) } 40 \mathrm{~g} \text { of potassium iodide }+100 \mathrm{~mL} \text { water. } \\
10 \mathrm{~mL} \text { of (a) is mixed with } 10 \mathrm{~mL} \text { of (b) and } 25 \mathrm{~mL} \text { of glacial acetic acid } \\
\text { is added. The solution is then diluted to } 100 \mathrm{~mL} \text { with distilled water. }\end{array}$ & Red & $\begin{array}{c}\text { Present } \\
\text { work }\end{array}$ \\
\hline 2 & $\begin{array}{l}\text { Van Urk's reagent }+2 \text { Drops of sample } \\
\text { extract (heat for } 5 \text { min at } 75^{\circ} \mathrm{C} \text { ) }\end{array}$ & $\begin{array}{l}0.1 \mathrm{~mL} 5 \% \text { Ferric chloride solution }+65 \% \mathrm{H}_{2} \mathrm{SO}_{4} \text { in } 100 \mathrm{~mL}+0.125 \mathrm{~g} \\
\text { paradimethyl amino benzaldehyde solution }\end{array}$ & Pink & [35] \\
\hline 3 & $\begin{array}{l}\text { I. } 1 \% \text { Aq. potassium ferricyanide } \\
\text { II. Con. } \mathrm{HCl}+2 \text { Drops of sample extract }\end{array}$ & $1 \mathrm{~g}$ of potassium ferricyanide was added in $100 \mathrm{~mL}$ of water & Blue & [35] \\
\hline
\end{tabular}

has given the effective results. Ethanol and xylene are less carcinogenic and found suitable for extraction of cypermethrin and transfluthrin. Extraction from cockroach and ant killer chalk (Zee) and $10 \%$ extract showed highest recoveries. Confirmation of cypermethrin and transfluthrin were done by TLC, spot tests, UV-visible spectroscopy, LC-MS and FT-IR. Hence by using ultrasonication, extraction of pyrethroids from cymbush and household insecticides can be done successfully.

\section{ACKNOWLEDGEMENTS}

The authors are greatly thankful to Department of Forensic Chemistry and Toxicology, Government Institute of Forensic Science, Aurangabad, India for providing the laboratory facilities and instrumentation. Special thanks to Dr S.G. Gupta, Director, Government Institute of Forensic Science, Aurangabad, India for support and encouragement in research work.

\section{REFERENCES}

1. U.S. Department of Health and Human Services, Toxicological Profile for Pyrethrins and Pyrethroids.Updated 9/2003.

http://www.atsdr.cdc.gov/toxprofiles/tp155.pdf.

2. S.M. Bradberry, S.A. Cage, A.T. Proudfoot and J.A. Vale, Toxicol. Rev., 24, 93 (2005); https://doi.org/10.2165/00139709-200524020-00003.

3. F. Cantalamessa, Arch. Toxicol., 67, 510 (1993); https://doi.org/10.1007/BF01969923.

4. T. Narahashi, Bull. World Health Organ., 44, 337 (1971).

5. D. Mueller-Beilschmidt, J. Pestic. Reform, 10, 32 (1990).

6. T. Narahashi, K.S. Ginsburg, K. Nagata, J.H. Song and H. Tatebayashi, Neurotoxicology, 19, 581 (1998).

7. W.N. Aldridge, Toxicology, 21, 89 (1990);

8. D.N. Bateman, J. Toxicol. Clin. Toxicol., 38, 107 (2000); https://doi.org/10.1081/CLT-100100924.

9. A. Anadón, M.R. Martinez-Larrañaga, M.J. Diaz and P. Bringas, Toxicol. Appl. Pharmacol., 110, 1 (1991); https://doi.org/10.1016/0041-008X(91)90284-L.

10. D.M. Soderlund, J.M. Clark, L.P. Sheets, L.S. Mullin, V.J. Piccirillo, D. Sargent, J.T. Stevens and M.L. Weiner, Toxicology, 171, 3 (2002); https://doi.org/10.1016/S0300-483X(01)00569-8.

11. M.J. Crawford, A. Croucher and D.H. Hutson, Pestic. Sci., 12, 399 (1981); https://doi.org/10.1002/ps.2780120406.

12. D.B. Barr, A.O. Olsson, L.-Y. Wong, S. Udunka, S.E. Baker, R.D. Whitehead Jr., M.S. Magsumbol, B.L. Williams and L.L. Needham, Environ. Health Perspect, 118, 742 (2010); https://doi.org/10.1289/ehp.0901275.

13. B. Kolmodin-Hedman, Swensson and M. Kerblom, Arch. Toxicol., 50, 27 (1982); https://doi.org/10.1007/BF00569234.

14. F. He, S. Wang, L. Liu, S. Chen, Z. Zhang and J. Sun, Arch. Toxicol., 63, 54 (1989); https://doi.org/10.1007/BF00334635.
15. P.Y. Yang, J.L. Lin, A.H. Hall, T.C. Tsao and M.S. Chern, J. Toxicol. Clin. Toxicol., 40, 107 (2002); https://doi.org/10.1081/CLT-120004397.

16. A.A. Ramadan, N.M. Bakry, A.S.M. Marei, A.T. Eldefrawi and M.E. Eldefrawi, Pestic. Biochem. Physiol., 32, 97 (1988); https://doi.org/10.1016/0048-3575(88)90002-8.

17. A. Sapiets, H. Swaine and M.J. Tandy, eds.: G. Zweig and J. Sherma, Cypermethrin, In: Synthetic Pyrethroids and Other Pesticides, Academic Press. vol. 13, 33 (1984).

18. L. Poulos, S. Athanaselis and A. Coutselinis, J. Toxicol. Clin. Toxicol., 19, 519 (1982); https://doi.org/10.3109/15563658208992509.

19. C. Nasuti, R. Gabbianelli, M.L. Falcioni, A. Di Stefano, P. Sozio and F. Cantalamessa, Toxicology, 229, 194 (2007); https://doi.org/10.1016/j.tox.2006.10.015.

20. A.K. Singh, M.N. Tiwari, O. Prakash and M.P. Singh, Curr. Neuropharmacol., 10, 64 (2012); https://doi.org/10.2174/157015912799362779.

21. Y. Shukla, A. Yadav and A. Arora, Cancer Lett., 182, 33 (2002); https://doi.org/10.1016/S0304-3835(02)00077-0.

22. U. Undeger and N. Basaran, Arch. Toxicol., 79, 169 (2005); https://doi.org/10.1007/s00204-004-0616-6.

23. L. Ahmad, A. Khan, M.Z. Khan, I. Hussain, F. Mahmood, M.K. Sleemi, L.A. Lodhi and I. Abdullah, Pestic. Biochem. Physiol., 103, 194 (2012); https://doi.org/10.1016/j.pestbp.2012.05.004.

24. A. Elbetieha, S.I. Daas, W. Khamas and H. Darmani, Arch. Environ. Contam. Toxicol., 41, 522 (2001); https://doi.org/10.1007/s002440010280.

25. J. Pauluhn and K. Ozaki, Regul. Toxicol. Pharmacol., 71, 78 (2015); https://doi.org/10.1016/j.yrtph.2014.11.003.

26. S. Babic, M. Petrovic and M. Kastelan-Macan, J. Chromatogr. A, 823, 3 (1998); https://doi.org/10.1016/S0021-9673(98)00301-X.

27. A.M. Nguyen, P.J. Marriott and J. Hughes, J. Biochem. Biophys. Methods, 43, 411 (2000); https://doi.org/10.1016/S0165-022X(00)00054-3.

28. S.P. Merchant, R.S. Bhise and S.S. Carpenter, J. Indian Soc. Toxicol., 7, 1 (2011).

29. S. Vaishya, R.S. Chandel and R. Singh, J. Indian Soc. Toxicol., 6, 11 (2010).

30. N. Shahzadi, M. Imran, M. Sarwar, A.S. Hashmi and M. Wasim, J. Agroaliment. Proc. Technol., 19, 167 (2013).

31. I. Rezic, A.J.M. Horvat, S. Babic and M. Kastelan-Macan, Ultrason. Sonochem., 12, 477 (2005);

https://doi.org/10.1016/j.ultsonch.2004.07.004.

32. Z. Sharif, Y.B.C. Man, N.S.A. Hamid and C.C. Keat, J. Chromatogr. A, 1127, 254 (2006); https://doi.org/10.1016/j.chroma.2006.06.007.

33. M.L. Feo, E. Eljarrat and D. Barceló, J. Chromatogr. A, 1217, 2248 (2010); https://doi.org/10.1016/j.chroma.2010.02.018.

34. G. Suresh, T.V. Rao and A. Ramesh, J. Pharmacy Chem., 9, 19 (2015).

35. R. Yadav, A Toxo-Analytical Study of Some Synthetic Pyrethroids, Chap. 2, pp. 31-51 (2002). 